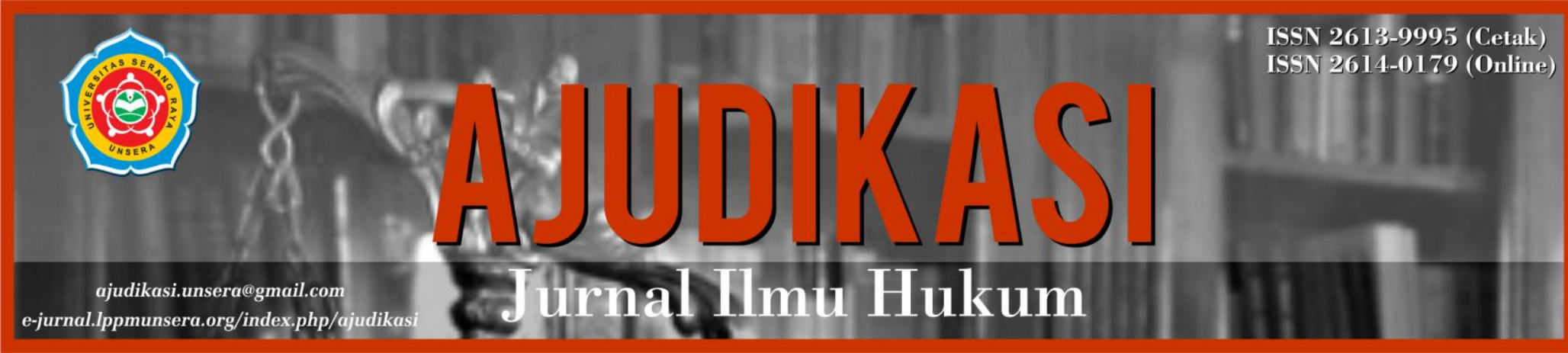

\title{
ANALISIS KEBIJAKAN PEMERINTAH DALAM PERLINDUNGAN SATWA LANGKA DI INDONESIA
}

\section{Novarisa Permatasari}

Program Pascasarjana Magister Hukum, Universitas Muhammadiyah Yogyakarta, D.I. Yogyakarta. Correspondent email : novarisapermatasari@yahoo.com

\begin{tabular}{lll}
\hline | Article History & $:$ & \\
$\mid$ Submission & $:$ & 25 April 2021 \\
$\mid$ Last Revissions & $:$ & 22 Juni 2021 \\
| Accepted & $:$ & 25 Juni 2021 \\
| Copyedits Approved & $:$ & 29 Juni 2021 \\
\hline
\end{tabular}

\begin{abstract}
Protection and management of conservation, biodiversity and ecosystems in Indonesia is very necessary, one of that is the protection of endangered species. The existence of endemic species in a conservation area can be an indicator that the protection and management of the area is running well and sustainable. The area of Indonesia's original natural forests is currently shrinking rapidly. So now animals life is increasingly threatened because of human growth that is more rapidly and human civilization that more sophisticated. Therefore, this journal aims to analyze the protection and preservation of endangered species in Indonesia's by using normative legal research methods. The approach method in this research is a statute approach with secondary data sources. The secondary data referred to include primary legal materials, secondary legal materials, and tertiary legal materials.
\end{abstract}

Keywords: Protection; Management; Rare Animal; Law Policy; Government. 


\section{A. PENDAHULUAN}

Indonesia adalah negara yang luas dan memiliki sumber daya alam dengan keanekaragaman hayati berlimpah atau sering dikenal sebagai negara mega biodiversity. Sehingga perlindungan dan pengelolaan konservasi dan keanekargaman hayati serta ekosistemnya sangat diperlukan, salah satu pilar penting adalah perlindungan terhadap jenis satwa langka. Terdapatnya jenis endemik dalam satu kawasan konservasi ataupun kawasan lainnya bisa menjadi indikator bahwa perlindungan dan pengelolaan kawasan tersebut berjalan dengan baik dan berkelanjutan. Menurut catatan pusat monitoring konservasi dunia (the World Conservation Monitoring Centre) kekayaan keanekaragaman hayati Indonesia antara lain 3.305 spesies amphibi, burung, mamalia dan reptil. Diantaranya, $31,1 \%$ nya endemik yang artinya, hanya terdapat di Indonesia dan $9.9 \%$ nya terancam punah. ${ }^{1}$

Pada era tahun 1970-an, hutan Indonesia menginjak babak baru. Masa era ini, deforestasi (menghilangnya lahan hutan) mulai menjadi masalah serius. Penebangan hutan komersial mulai dibuka secara besar - besaran. Konsesi pembalakan hutan (illegal logging) yang mulanya bertujuan untuk mengembangkan sistem produksi kayu untuk kepentingan masa depan, pada akhirnya melaju menuju degradasi hutan yang serius. Luas hutan alam asli Indonesia pun menyusut dengan kecepatan yang sangat mengkhawatirkan. Sehingga saat ini kehidupan satwa semakin terancam karena pertumbuhan manusia semakin pesat dan peradaban manusia semakin canggih.

Salah satu cara untuk mengatasinya adalah dengan peraturan yang dibuat oleh pemerintah. Hal itu dilakukan agar satwa langka mendapatkan perlindungan guna mempertahankan habitatnya secara berkesinambungan. Sehingga keberadaan satwa tersebut lebih terjaga dan juga dapat meningkatkan kualitas nilai serta keanekaragamannya. Undang-Undang yang mengatur tentang larangan perdagangan satwa yang dilindungi, dewasa ini dengan perkembangan teknologi yang semakin pesat, pemerintah melalui Badan Konservasi Sumber Daya Alam menemukan pelanggaran penjualan satwa langka melalui media internet yang memanfaatkan jejaring sosial seperti facebook dan twitter. Keberadaan jejaring sosial yang melakukan perdagangan illegal dapat membahayakan kelestarian satwa langka seperti Burung elang dan Kukang yang dengan sengaja dicuri dan diperjualbelikan secara illegal. Undang-Undang Nomor 5 Tahun 1990 Tentang Konservasi Sumber Daya Alam Hayati dan Ekosistemnya, perdagangan hewan yang dilindungi tersebut bertentangan dengan Peraturan Pemerintah Nomor 7 Tahun 1999 Tentang Pengawetan Jenis Satwa dan Tumbuhan. Perdagangan hewan yang dilindungi yang dilakukan melalui media internet seharusnya dapat

\footnotetext{
1 Fathi Hanif, "Upaya Perlindungan Satwa Liar Indonesia Melalui Instrumen Hukum Dan Perundang-
} Undangan," Jurnal Hukum Lingkungan Indonesia 2, no. 2 (2021): 30, https://doi.org/10.38011/jhli.v2i2.24. 
dikenakan pula hukuman menurut UndangUndang Nomor 11 Tahun 2008 Tentang Informasi dan Transaksi Elektronik.

Berkurangnya luas hutan menjadi faktor penting penyebab terancam punahnya satwa liar Indonesia, karena hutan menjadi habitat utama bagi satwa liar itu. Daratan Indonesia pada tahun 1950-an dilaporkan sekitar 84\% berupa hutan (sekitar 162 juta ha), namun kini pemerintah menyebutkan bahwa luasan hutan Indonesia sekitar 138 juta hektar. Namun berbagai pihak menyebutkan data yang berbeda bahwa luasan hutan Indonesia kini tidak lebih dari 120 juta hektar. ${ }^{2}$ Diikuti dengan permasalahan konversi hutan hingga penyusutan kuantitas dan kualitas satwa langka yang terjadi juga menjadi ancaman serius bagi kelestarian satwa langka.

Berdasarkan pernyataan diatas maka, segala daya upaya yang di lakukan secara sadar oleh setiap orang maupun lembaga pemerintah, swasta yang bertujuan mengusahakan pengamanan, penguasaan dan pemenuhan kesehjahteraan hidup atau dengan kata lain perlindungan hukum dapat diaartikan sebagai suatu gambaran dari fungsi hukum, yaitu konsep dimana hukum dapat memberikan suatu keadilan dan ketertiban. Sehingga, majunya negara yang berhukum dapat diupayakan dengan pemerintah yang tidak membiarkan aturan-aturan hukum yang sudah diatur, tetapi juga menjalankan aturan tersebut sesuai dengan apa yang sudah dibuat untuk mendapatkan kepastian hukum.

\section{B. METODE PENELITIAN}

Untuk dapat mengetahui dan membahas permasalahan yang ada diperlukan adanya pendekatan dengan metode penelitian hukum normatif. Metode pendekatan dalam penelitian ini adalah pendekatan peraturan perundang-undangan (statue approach). ${ }^{3}$ Serta, jenis dan sumber data yang akan digunakan sebagai dasar untuk menunjang penelitian ini adalah data yang dikumpulkan berasal dari data sekunder. Data sekunder dimaksud antara lain meliputi bahan hukum primer, bahan hukum sekunder dan bahan hukum tertier. ${ }^{4}$

\section{HASIL DAN PEMBAHASAN}

\section{Perlindungan dan Pelestarian Satwa Langka di Indonesia}

Suatu jenis satwa dapat digolongkan sebagai satwa yang dilindungi apabila telah memenuhi tiga kriteria yaitu pertama memenuhi populasi yang kecil, kedua adanya penurunan yang tajam pada jumlah individu di alam dan ketiga daerah penyebaranya terbatas (endemik). Hal ini sesuai dengan ketentuan Pasal 5 ayat (1)

\footnotetext{
${ }^{2}$ ProFauna, "No Fakta Tentang Satwa Liar Indonesia," www.profauna.net, 2003.

${ }^{3}$ Peter Mahmud Marzuki, Penelitian Hukum, Cetakan ke (Jakarta: Kencana, 2008) Hlm. 29

${ }^{4}$ Zainal Asikin. Amiruddin, Pengantar Metode Penelitian Hukum, Raja Grafindo Persada (Jakarta: Raja Grafindo Persada, 2004) Hlm. 30.
} 
Peraturan Pemerintah No. 7 Tahun 1999 tentang Pengawetan Jenis Tumbuhan dan Satwa. Pernyataan tersebut penting untuk diketahui untuk mempermudah dalam menentukan jenis satwa langka dilindungi dan kepunahan satwa langka dapat dicegah dengan diciptakannya perlindungan hukum dan konservasi terhadap satwa langka yang ada. Menurut Satjipto Rahardjo, Perlindungan hukum adalah memberikan pengayoman terhadap hak asasi manusia (HAM) yang dirugikan orang lain dan perlindungan itu diberikan kepada masyarakat agar dapat menikmati semua hak-hak yang diberikan oleh hukum. ${ }^{5}$

Selanjutnya menurut Phillipus M. Hadjon bahwa perlindungan hukum bagi rakyat sebagai tindakan pemerintah yang bersifat preventif dan resprensif. Perlindungan Hukum yang preventif bertujuan untuk mencegah terjadinya sengketa, yang mengarahkan tindakan pemerintah bersikap hati-hati dalam pengambilan keputusan berdasarkandiskresi dan perlindungan yang resprensif bertujuan untuk mencegah terjadinya sengketa, termasuk penanganannya di lembaga peradilan. ${ }^{6}$ Ada terdapat beberapa penyebab terkait kepunahan satwa langka, yakni:

a. Perburuan Ilegal

Perburuan ilegal yang semakin marak terutama dengan majunya teknologi. Modus dan taktik pemburu beserta pedagang ilegal terus berkembang. Dwi Adhiasto, peneliti dan ahli biokriminologi program Bangun Indonesia untuk Jaga Alam demi Berkelanjutan (BIJAK) USAID mengatakan bahwa di antara mereka melakukan simbiosis mutualisme, yakni saling mendukung demi ketersediaan pemasokan barang dagangan. Pemetaan rantai kejahatan pemburu hingga pedagang dan penampung besar. ${ }^{7}$ Direktur Lingkungan Hidup USAID, Mattew Burton juga mengatakan bahwa perdagangan satwa ilegal tidak hanya merugikan keseimbangan ekosistem, tetapi juga masyarakat yang bergantung pada hutan juga sektor pariwisata dan lainnya.

b. Penyakit genetik

Penyakit genetik yang mematikan yang dapat menyebabkan kepunahan pada satwa yang terlanjur memiliki populasi berukuran kecil. Kurangnya alternatif pasangan kawin baik di alam maupun penangkaran meningkatkan kecenderungan perkawinan sekerabat. Karena kerabat cenderung memiliki komposisi genetik serupa, perkawinan sekerabat menurunkan variasi genetik yang diperlukan untuk memperluas spektrum kerja sistem imun tubuh.

\footnotetext{
${ }^{5}$ Satjipto Raharjo, Ilmu Hukum (Bandung: PT. Citra Aditya Bakti, 2000) Hlm.69.

${ }^{6}$ Ibid, Hlm. 54.

${ }^{7}$ Asti. Dian, "Perdagangan Satwa Ilegal Ada Di Sekitar Kita Begini Kondisinya,” www.mongabay.co.id, 2018.
} 
Terakumulasinya mutasi berbahaya akibat perkawinan sekerabat juga dapat menurunkan tingkat harapan hidup suatu populasi. ${ }^{8}$

Pada sebagian besar hewan bertulang belakang, termasuk manusia, fungsi tubuh sangat bergantung pada gen-gen yang membawa informasi yang diperlukan untuk menjaga sel tubuh tetap sehat. Gen biasanya mempunyai dua salinan dalam sel, dan setiap salinan bisa saja memiliki variasi. Variasi dalam salinan gen ini disebut alel. Alel-alel ini dapat mengalami mutasi yang merusak fungsi sel. Ketika satu salinan mengalami mutasi dan salinan lain tidak, gen tersebut biasanya masih dapat berfungsi. Ketika perkawinan sekerabat terjadi, peluang bertemunya dua salinan yang membawa mutasi yang dapat mengganggu fungsi gen semakin besar. Mutasi gen yang merusak biasanya dapat terkumpul dalam suatu populasi dikarenakan tidak berhasil dieleminasi oleh seleksi alam. Seleksi alam tidak dapat bekerja karena fungsi tubuh tidak langsung terganggu. ${ }^{9}$

Dengan demikian, mutasi tersebut berpeluang besar diturunkan ke generasi selanjutnya. Jika tidak ada variasi baru dan perkawinan sekerabat terus terjadi, mutasi-mutasi berbahaya ini dapat terkumpul sampai ke taraf yang mematikan. Analisis terhadap genom mammoth berbulu (Mammuthus primigenius), kerabat gajah yang sudah punah pada Zaman Es, menunjukkan bahwa individu terakhir spesies ini menyimpan banyak mutasi berbahaya sebelum akhirnya mati. Analisis genomik terhadap hewan-hewan terancam punah semisal cheetah Afrika (Acinonyx jubatus), serigala abu-abu (Canis lupus), dan burung ibis endemik Jepang (Nipponia nippon) juga menunjukkan tren yang serupa. ${ }^{10}$

c. Konversi hutan

Hutan yang terus dieksploitasi secara berlebihan serta hutan yang dibakar guna dijadikan pemukiman merupakan salah satu ancaman berkurangnya populasi satwa langka tersebut. Selanjutnya, illegal logging yang merupakan suatu aktivitas penebangan liar yang telah berkembang pesat sejak tahun 1970-an. Dimana pada masa ini mulai bertumbuhnya industri perkayuan di Indonesia. Industri - Industri perkayuan ini awalnya dimaksudkan untuk mengembangkan produksi kayu Indonesia di masa yang akan datang. Namun pengembangan produksi kayu ini malah mengarah pada munculnya praktik illegal logging yang mengakibatkan terjadinya degradasi hutan yang serius.

Kondisi semakin parah dengan adanya kegiatan konversi hutan menjadi perusahaan maupun untuk kegiatan tambang dalam skala besar. Cukup banyak

\footnotetext{
${ }^{8}$ Sabhrina Aninta, “Mengapa Satwa Langka Rentan Punah? Genetika Jelaskan,”www.sains.kompas.com, 2019.

${ }^{9}$ Ibid.

${ }^{10}$ Ibid.
} 
fakta di lapangan tentang nasib satwa dilindungi yang terekspos media massa cetak, elektronik, maupun media sosial. Sementara itu di habitatnya mereka juga semakin terjepit, akibat pembabatan kawasan hutan untuk perkebunan, pertambangan, maupun alih fungsi lain.

Hingga saat ini, Indonesia telah memasuki situasi krisis yang mengancam keberlangsungan hidup satwa-satwa langka di habitatnya. Setiap tahun, satwa-satwa kehilangan ratusan hektar hutan yang menjadi tempat tinggal dan habitatnya seperti halnya penggunaan kawasan hutan non-prosedural, perluasan permukiman dan kebakaran hutan. Mengikuti perkembangan tersebut, tentunya pemerintah belum maksimal dalam memberikan perlindungan hukum terhadap hewan langka yang mendapatkan perlakuan tidak wajar oleh oknum-oknum yang tidak bertanggung jawab. Sebagaimana Fitzgerald yang mengutip istilah teori perlindungan hukum dari Salmond bahwa hukum bertujuan mengintegrasikan dam mengkoordinasikan berbagai kepentingan dalam masyrakat karena dalam suatu lalulintas kepentingan, perlindungan terhadap kepentingan tertentu dapat dilakukan dengan cara membatasi berbagai kepentingan di lain pihak. Kepentingan hukum adalah mengurusi hak dan kepentingan manusia, sehingga hukum memiliki otoritas tertinggi untuk menentukan kepentingan manusia yang perlu diatur dan dilindungi.

Perlindungan hukum harus melihat tahapan yakni perlindungan hukum lahir dari suatu ketentuan hukum dan segala peraturan hukum yang diberikan oleh masyarakat yang pada dasarnya merupkan kesepakatan masyarakat tersebut untuk mengatur hubungan perilaku antara anggota-anggota masyarakat dan antara perseorangan dengan pemerintah yang dianggap mewakili kepentingan masyarakat. ${ }^{11}$ Konsep perlindungan hukum terhadap satwa langka menurut Muchsin perlindungan hukum merupakan suatu hal yang melindungi subjek-subjek hukum melalui peraturan perundangundangan yang berlaku dan dipaksakan pelaksanaannya dengan suatu sanksi. Perlindungan hukum dapat dibedakan menjadi dua, yaitu perlindungan hukum preventif dan perlindungan hukum represif.

a) Perlindungan Hukum Preventif

Perlindungan yang diberikan oleh pemerintah dengan tujuan untuk mencegah sebelum terjadinya pelanggaran. Hal ini terdapat dalam peraturan perundang undangan dengan maksud untuk mencegah suatu pelanggaran serta memberikan rambu-rambu atau batasan-batasan dalam melakukan suatu kewajiban. Salah satu bentuk peraturan yang dibuat oleh pemerintah yakni

${ }^{11}$ Satjipto Raharjo, Op.cit., Hlm. 53 
terdapat pada Undang-Undang Nomor 5 Tahun 1990 tentang Konservasi Sumber Daya Alam Hayati dan Ekosistemnya. ${ }^{12}$

Undang-Undang Nomor 5 Tahun 1990 Tentang Konservasi Sumber

Daya Alam Hayati dan Ekosistemnya tidak secara eksplisit dijelaskan secara langsung di dalam peraturan tersebut. Namun, merujuk pada Undang-undang ini terdapat kaitannya pada :

Pasal 19:

1) Setiap orang dilarang melakukatn kegiatan yang dapat mengakibatkan perubahan terhadap keutuhan kawasan suaka alam.

2) Ketentuan sebagaimana dimaksud dalam ayat ( 1) tidak termasuk kegiat an pembinaan Habitat untuk kepentingan satwa di dalam suaka marga satwa.

3) Perubahan terhadap keutuhan kawasan suaka alam sebagaimana dimaksud dalam ayat (1) meliputi mengurangi, menghilangkan fungsi dan luas kawasan suaka alam, serta menambah jenis tumbuhan dan satwa lain yang tidak asli.

Pasal 21 ayat 2:

"Setiap orang dilarang untuk:

a. menangkap, melukai, membunuh, menyimpan, memiliki, memelihara, mengangkut, dan memperniagakan satwa yang dilindungi dalam keadaan hidup;

b. menyimpan, memiliki, memelihara, mengangkut, dan memperniagakan satwa yang dilindungi dalam keadaan mati;

c. mengeluarkan satwa yang dilindungi dari suatu tempat di Indonesia ke tempat lain di dalam atau di luar Indonesia;

d. memperniagakan, menyimpan atau memiliki kulit, tubuh, atau bagian-bagian lain satwa yang dilindungi atau barang-barang yang dibuat dari bagian-bagian tersebut atau mengeluarkannya dari suatu tempat di Indonesia ke tempat lain di dalam atau di luar Indonesia;

e. mengambil, merusak, memusnahkan, memperniagakan, menyimpan atau memiliki telur dan atau sarang satwa yang dillindungi."

Pasal 22:

1) Pengecualian dari larangan sebagaimana dimaksud dalam Pasal 21 hanya dapat dilakukan untuk keperluan penelitian, ilmu pengetahuan, dan/atau penyelamatan jenis tumbuhan dan satwa yang bersangkutan.

2) Termasuk dalam penyelamatan sebagaimana dimaksud dalam ayat (1) adalah pemberian atau penukaran jenis tumbuhan dan satwa kepada pihak lain di luar negeri dengan izin Pemerintah.

\footnotetext{
${ }^{12}$ Safrizal, "Perlindungan Hukum Terhadap Satwa Liar (Studi Konflik Gajah Dengan Manusia Di Aceh Timur) Menurut Hukum Pidana Islam” (Universitas Islam Negeri Ar-Raniry, 2019) Hlm. 17.
} 
3) Pengecualian dari larangan menangkap, melukai, dan membunuh satwa yang dilindungi dapat pula dilakukan dalam hal oleh karena suatu sebab satwa yang dilindungi membahayakan kehidupan manusia.

4) Ketentuan lebih lanjut sebagaimana diinaksud dalam ayat (1), ayat (2), dan ayat (3) diatur dengan Peraturan Pemerintah.

Pasal 23 :

1) Apabila diperlukan, dapat dilakukan pemasukan tumbuhan dan satwa liar dari luar negeri ke dalam wilayah Negara Republik Indonesia.

2) Ketentuan lebih lanjut sebagaimana dimaksud dalam ayat (1) diatur dengan Peraturan Pemerintah.

Pasal 24:

1) Apabila terjadi pelanggaran terhadap larangan sebagaimana dimaksud dalam Pasal 21, tumbuhan dan satwa tersebut dirampas untuk negara.

2) Jenis tumbuhan dan satwa yang dilindungi atau bagian-bagiannya yang dirampas untuk negara dikembalikan ke habitatnya atau diserahkan kepada lembaga-lembaga yang bergerak di bidang konservasi tumbuhan dari satwa, kecuali apabila keadaannya sudah tidak memungkinkan untuk dimanfaatkan sehingga dinilai lebih baik dimusnahkan.

Pasal 25:

1) Pengawasan jenis tumbuhan dan satwa yang dilindungi hanya dapat dilakukan dalam bentuk pemeliharaan atau pengembangbiakan oleh lembaga-lembaga yang dibentuk untuk itu.

2) Ketentuan lebih lanjut sebagaimana dimaksud dalam ayat (1) diatur dengan Peraturan Pemerintah.

Pasal 33 :

1. Setiap orang dilarang melakukan kegiatan yang dapat mengakibatkan perubahan terhadap keutuhan zona inti taman nasional.

2. Perubahan terhadap keutuhan zona inti taman nasional sebagaimana dimaksud dalam ayat (1) meliputi mengurangi, menghilangkan fungsi dan luas zona inti taman nasional, serta menambah jenis tumbuhan dan satwa lain yang tidak asli.

3. Setiap orang dilarang melakukan kegiatan yang tidak sesuai dengan fungsi zona pemanfaatan dan zona lain dari taman nasional, taman hutan raya, dan taman wisata alam.

Terlihat dari aturan diatas bagaimana pemerintah Indonesia yang dengan seksama memperhatikan keberadaan satwa yang langka. Sehingga secara 
preventif pemerintah telah mengambil tindakan untuk melakukan perlindungan terhadap satwa langka yang terdapat dalam lingkungan Indonesia. Dengan demikian keberadaan satwa langka menjadi tanggungjawab pemerintah melalui regulasi yang ada untuk menjaga kelestarian satwa baik melalui perlindungan tempat tinggal maupun melalui konservasi.

b) Perlindungan Hukum Represif

Perlindungan hukum represif merupakan perlindungan akhir berupa sanksi seperti denda, penjara, dan hukuman tambahan yang diberikan apabila sudah terjadi sengketa atau telah dilakukan suatu pelanggaran. ${ }^{13}$ Ketentuan ancaman hukuman terdapat dalam Undang-undang Nomor 5 Tahun 1990 Tentang Konservasi Sumber Daya Alam Hayati dan Ekosistemnya pada BAB XII tentang Ketentuan Pidana Pasal 40 sebagai berikut ini.

1) Barangsiapa dengan sengaja melakukan pelanggaran terhadap ketentuan sebagaimana dimaksud dalam Pasal 19 ayat (1) dan Pasal 33 ayat (1) dipidana dengan pidana penjara paling lama 10 (sepuluh) tahun dan denda paling banyak $R p$ 200.000.000,00 (dua ratus juta rupiah).

2) Barangsiapa dengan sengaja melakukan pelanggaran terhadap ketentuan sebagaimana dimaksud dalam Pasal 21 ayat (1) dan ayat (2) serta Pasal 33 ayat (3) dipidana dengan pidana penjara paling lama 5 (lima) tahun dan denda paling banyak $R p$ 100.000.000,00(seratus juta rupiah).

3) Barangsiapa karena kelalaiannya melakukan pelanggaran terhadap ketentuan sebagaimana dimaksud dalam Pasal 19 ayat (1) dan Pasal 32 ayat (1) dipidana dengan pidana kurungan paling lama 1 (satu) tahun dan denda paling banyak Rp. 100.000.000,00 (seratus juta rupiah).

4) Barangsiapa karena kelalaiannya melakukan pelanggaran terhadap ketentuan sebagaimana dimaksud dalam Pasal 21 ayat (1) dan ayat (2) serta Pasal 33 ayat (3) dipidana dengan pidana kurungan paling lama 1 (satu) tahun dan denda paling banyak $R p$ 50.000.000,00 (lima puluh juta rupiah). (5) Tindak pidana sebagaimana dimaksud dalam ayat (1) dan ayat (2) adalah kejahatan dan tindak pidana sebagaimana dimaksud dalam ayat (2) dan ayat (4) adalah pelanggaran.

Perlindungan hukum represif dimaksudkan dengan penegakkan sanksi bagi siapapun yang melakukan pelanggaran dan/atau perbuatan yang dilarang berdasarkan ketentuan perundang-undangan. Dengan demikian, pemerintah memberikan peringatan sekaligus ancaman bagi para pelaku tindak kehajatan terhadap perlindungan satwa langka dengan penerapan sanksi pidana.

\footnotetext{
${ }^{13}$ Ibid.
} 
Peraturan perundang-undangan merupakan salah satu instrument kebijakan negara yang dibuat untuk menyelesaikan masalah baik yang sudah, sedang, atau kemungkinan terjadi di masa depan yang bersifat antisipasi atau prospektif. $^{14}$ Konsespsi Negara hukum memberikan jaminan perlindungan secara preventif yaitu terhadap perbuatan-perbuatan yang bertentangan dengan peraturan hukum formil yang ditetapkan oleh Negara. Sedangkan secara represif, bentuk perlindungan hukum berupa penegakkan hukum terhadap perbuatan-perbuatan yang bertentangan dengan peraturan perundangundangan. $^{15}$

\section{Kebijakan Pemerintah Tentang Perlindungan Satwa Langka}

Indonesia adalah negara hukum yang pada dasarnya segala tingkah laku manusia haruslah diatur berdasarkan dengan adanya hukum yang ada hal tersebut sesuai yang tertuang dalam pembukaan Undang - Undang dasar 1945 Pasal 1 Ayat 3 yang menyatakan Negara Indonesia adalah Negara hukum. Oleh karena itu hukum bekerja dengan cara memberikan petunjuk tentang tingkah laku setiap manusia dan karena itu pula hukum berupa norma yang hidup dan berkembang didalam masyarakat. ${ }^{16}$

Saat ini perlindungan satwa langka sangat ketat dilakukan oleh pemerintah maupun masyarakat yang terkait dalam lembaga konservasi. Akibat dari kegiatan yang dilakukan oknum, dapat dipastikan setiap tahunnya keberadaan satwa-satwa tersebut semakin menurun jumlah populasinya dan sulit ditemui di habitat aslinya. Jika kondisi ini dibiarkan terus berlanjut maka kelangkaan dan kepunahan satwa langka dilindungi tidak dapat terelakkan sehingga keberagaman satwa di Indonesia hanya akan menjadi cerita bagi anak cucu kita nantinya, serta akan memberikan dampak negatif terhadap ekosistem yang alami.

Secara hukum upaya pemerintah dalam melindungi satwa langka dari ancaman kepunahan dilakukan dengan dikeluarkannya peraturan perundang-undangan yang telah disebutkan sebelumnya yakni Undang-Undang Nomor 5 Tahun 1990 tentang Konservasi Sumber Daya Alam Hayati dan Ekosistemnya selanjutnya di ikuti dengan ditetapkanya Peraturan Pemerintah Nomor 13 Tahun 1994 tentang Perburuan Satwa Buru, Peraturan Pemerintah Nomor 18 Tahun 1994 tentang Pengusahaan Pariwisata Alam di Zona Pemanfaatan Taman Nasional, Peraturan Pemerintah Nomor 68 Tahun

\footnotetext{
${ }^{14}$ Rokilah Rokilah, "The Role of the Regulations in Indonesia State System," Ajudikasi : Jurnal Ilmu Hukum Vol. 4, No. 1 (2020): 29-38, https://doi.org/10.30656/ajudikasi.v4i1.2216.

${ }^{15}$ Fuqoha Fuqoha, Indrianti Azhar Firdausi, and Arga Eka Sanjaya, "Perlindungan Hukum Terhadap Intervensi Pemberitaan Dalam Kerangka Kemerdekaan Pers Nasional," Ajudikasi : Jurnal Ilmu Hukum Vol.3, No. 1 (2019): 75, https://doi.org/10.30656/ajudikasi.v3i1.1436.

${ }^{16}$ Soerjono Soekanto, Sosiologi Suatu Pengantar, Cetakan 1 (Jakarta: Raja Grafindo Persada, 2007) Hlm. 179.
} 
1998 tentang Kawasan Suaka Alam dan Kawasan Pelestarian Alam, dan Peraturan Pemerintah Nomor 7 Tahun 1999 tentang Pengawetan Jenis Tumbuhan dan Satwa, serta Peraturan Pemerintah Nomor 8 Tahun 1999 tentang Pemanfaatan Jenis Tumbuhan dan Satwa. Dengan adanya aturan yang jelas penegakan hukum dapat berjalan lebih efektif untuk melindungi satwa khusunya satwa langka.

Untuk melestarikan keberadaan satwa langka tersebut, pemerintah melakukan upaya konservasi sebagaimana dalam Undang-Undang No. 5 Tahun 1990 tentang Konservasi Sumber Daya Alam Hayati dan Ekosistemnya disebutkan dalam Pasal 1 ayat (2) sebagai berikut :

"Konservasi sumber daya alam hayati adalah pengelolaan sumber daya alam hayati yang pemanfaatannya dilakukan secara bijaksana untuk menjamin kesinambungan persediaannya dengan tetap memelihara dan meningkatkan kualitas keanekaragaman dan nilainya. "17

Konservasi ini dilakukan melalui tiga kegiatan yaitu: ${ }^{18}$

a. perlindungan sistem penyangga kehidupan,

b. pengawetan keanekaragaman jenis tumbuhan dan satwa beserta ekosistemnya, dan;

c. pemanfaatan secara lestari sumber daya alam hayati dan ekosistemnya.

Selain itu, masyarakat pun memiliki andil yang besar dalam upaya pemerintah melindungi dan melestarikan satwa langka serta habitat alaminya sehingga kepunahan satwa langka dapat teratasi. Peran masyarakat pun menjadi elemen yang paling penting karena kekuatan pemerintah semata sangatlah kecil jika dibandingkan dengan tantangan yang begitu besar. Secara hukum upaya pemerintah Indonesia dalam melindungi satwa langka dari ancaman kepunahan sudah dilakukan dengan dikeluarkannya peraturan perundang-undangan yang juga mengatur terkait sanksi yang akan diberikan bagi oknum maupun pelaku tindak kejahatan terhadap satwa langka. Menurut peneliti dengan adanya berbagai macam bentuk hukum yang sudah terbentuk, maka dengan adanya Undang-Undang No. 5 Tahun 1990 seharusnya penegak hukum harus bertindak tegas dan adil terhadap satwa langka. Jika tidak secepatnya dilakukan maka bukan hanya satwa langka saja yang akan punah, tetapi juga berbagai spesies tumbuhan dan binatang liar lainnya. Jika hal ini terjadi maka manusia akan mengalami kerugian yang sangat besar karena ketika terjadi kepunahan maka tidak akan pernah dapat dimunculkan lagi.

\footnotetext{
17 Pasal 1 ayat (2) Undang-Undang No. 5 Tahun 1990 tentang Konservasi Sumber Daya Alam Hayati dan Ekosistemnya.

${ }^{18}$ Ibid, Pasal 5.
} 
Selain itu, sebagaimana yang kita ketahui, adanya kebijakan hukum yang dibuat pemerintah yakni sistem Online Single Submission (OSS) sebagai usaha peningkatan keterpaduan dan digitalisasi perizinan berusaha juga menimbulkan permasalahan baru. Dengan berpayung hukum Peraturan Pemerintah No. 24 Tahun 2018 tentang Pelayanan Perizinan Berusaha Terintegrasi Secara Elektronik. Adapun konsep yang diusung dalam PP ini adalah mengubah rezim perizinan terdahulu dengan cara menerbitkan Nomor Induk Berusaha (NIB), Izin Usaha, dan Izin Lokasi (tanpa komitmen) di awal. Kemudian komitmen dasar seperti IMB, Izin Lingkungan (AMDAL), dan izin lainnya dipenuhi secara bertahap sesuai jangka waktu yang diatur dalam PP OSS. ${ }^{19}$

Sistem terbaru tersebut masih banyak terdapat kendala apalagi dengan adanya omnibus law yang memangkas aturan-aturan yang menghambat. Pelayanan Perizinan Berusaha Terintegrasi Secara Elektronik atau Online Single Submission (OSS) dalam pelaksanaan OSS banyak kritik yang datang dari berbagai pihak yang berujung pada judicial review ke Mahkamah Agung (MA). Uji materi tersebut dilayangkan oleh Koalisi Masyarakat Sipil Tolak Perizinan Ngawur, seperti ICEL, Walhi, YLBHI, Sawit Watch, Solidaritas Perempuan, KNTI, Kaoem Telapak, JATAM Kaltim dan sejumlah lembaga serta individu ini mendaftarkan uji materi terhadap PP tersebut. ${ }^{20}$ Beberapa organisasi masyarakat sipil yang fokus membidangi isu lingkungan hidup itu menilai PP No. 24 Tahun 2018 dalam percepatan izin usaha berbasis komitmen yang diterbitkan melalui mekanisme OSS mengabaikan perlindungan lingkungan hidup. Padahal di Undang-Undang No. 32 Tahun 2009 tentang Perlindungan dan Pengelolaan Lingkungan Hidup, ditegaskan bahwa izin lingkungan merupakan syarat untuk mendapat izin usaha dan/atau kegiatan. Tapi melalui OSS, izin lingkungan itu hanya sekedar komitmen dari pelaku usaha untuk memenuhinya yang bisa diurus setelah izin usaha terbit. Peletakkan wajib AMDAL setelah terbitnya NIB justru melemahkan posisi AMDAL yang selama ini berfungsi sebagai pengambil keputusan.

Sistem OSS yang diluncurkan oleh Pemerintah sebagai suatu sistem yang masih hijau, tentu memiliki kekurangan di sana-sini, baik dalam melihat OSS sebagai suatu sistem yang ideal, maupun dalam melihat OSS sebagai suatu sistem praktis yang telah diterapkan oleh Pemerintah sebagai regulator. Tumpang-tindih kewenangan (atau persepsi mengenai hal itu) juga membingungkan beberapa pihak pemangku kepentingan. Sehingga perlu adanya reformasi perizinan usaha yang lebih dalam lagi.

Hal diatas tentunya dapat semakin memperparah keadaan salah satunya keberadaan lingkungan hidup yang dimana banyak menjadi rumah bagi satwa langka.

\footnotetext{
${ }^{19}$ Fitria Novia Heriani, "Sejumlah Hambatan Yang Perlu Disempurnakan Dalam OSS," www.hukumonline.com, 2019.

${ }^{20}$ Ibid.
} 
Sehingga kepastian atas kebijakan hukum yang telah dibuat masih dipertanyakan hingga saat ini. Sebagaimana yang kita ketahui, hukum dan kepastian adalah dua hal yang sangat sulit untuk dipisahkan. Hukum ada adalah untuk adanya kepastian, adanya kepastian juga menjadikan hukum itu lebih ditaati. Untuk mewujudkan adanya kepastian maka hukum itu harus diciptakan terlebih dahulu sebelum perbuatanperbuatan yang diatur dalam hukum itu dilakukan, sehingga masyarakat menjadi tahu apa yang boleh dan apa yang tidak boleh dilakukan serta mengetahui konsekuensinya kalau mereka berbuat bertentangan atau melawan hukum. Kepastian memiliki arti "ketentuan; ketetapan" sedangkan jika kata "kepastian" digabungkan dengan kata "hukum" maka menjadi kepastian hukum, yang diartikan sebagai perangkat hukum suatu negara yang mampu menjamin hak dan kewajiban setiap warga negara. ${ }^{21}$

Hukum mengandung kepastian manakala hukum itu dapat menyebabkan perilaku manusia, baik individu, kelompok, maupun organisasi terikat dan berada dalam koridor yang sudah digariskan oleh aturan hukum itu sendiri. Nilai kepastian inilah yang harus ada dalam setiap hukum yang dibuat sehingga dapat memberikan rasa keadilan dan menciptakan ketertiban. Kepastian merupakan ciri yang tidak dapat dipisahkan dari hukum, terutama yang merupakan hukum positif atau peraturan perundang-undangan atau hukum tertulis. Hukum tanpa nilai kepastian akan kehilangan makna karena tidak dapat lagi digunakan sebagai pedoman perilaku bagi setiap orang. Kepastian mengandung beberapa arti, diantaranya adanya kejelasan, tidak menimbulkan multitafsir, tidak menimbulkan kontradiktif, dan dapat dilaksanakan. Hukum harus berlaku tegas di dalam masyarakat, mengandung keterbukaan sehingga siapapun dapat memahami makna atas suatu ketentuan hukum. Hukum yang satu dengan yang lain tidak boleh kontradiktif sehingga tidak menjadi sumber keraguan. ${ }^{22}$

Upaya pemerintah Indonesia dalam melindungi satwa langka sudah baik tetapi masih kurang, mengingat kondisi geografis Indonesia serta modus perdagangan yang sangat licin. Karena perdagangan liar tidak hanya berdampak langsung secara ekonomis tapi juga pada kedaulatan Indonesia. Maka, dari penjelasan tersebut dapat disimpulkan bahwa perlindungan satwa di Indonesia belum sesuai dengan kebijakan yang telah dibuat oleh pemerintah. Sehingga kepastian dalam hukum belum terbentuk secara sempurna. Selain itu, akan sangat lebih baik jika peraturan mengenai Pelayanan Perizinan Berusaha Terintegrasi Secara Elektronik atau Online Single Submission (OSS) di evaluasi ulang sistemasinya. Serta, akan sangat mengganggu dan bertabrakan dengan kebijakan yang telah ditetapkan sebelumnya karena sampai saat ini keberadaan

\footnotetext{
${ }^{21}$ Nyoman Gede Remaja, "Makna Hukum Dan Kepastian Hukum," Kertha Widya: Jurnal Hukum 2, no. 1 (2014): 1-26.

${ }^{22}$ Ibid.
} 
satwa langka sangat rentan beresiko akibat adanya kegiatan manusia maupun oknum yang tidak bertanggungjawab.

\section{KESIMPULAN}

Adapun kesimpulan yang dirangkum penulis berdasarkan pembahasan di atas yakni:

1. Kepunahan satwa langka di Indonesia saat ini dapat dicegah dengan diciptakannya perlindungan hukum dan konservasi terhadap satwa langka yang ada. Penyebab terkait kepunahan satwa langka berupa a) Perburuan Ilegal; b) Penyakit genetik; dan c) Konversi hutan. Satwa-satwa kehilangan ratusan hektar hutan yang menjadi tempat tinggal dan habitatnya seperti halnya penggunaan kawasan hutan nonprosedural, perluasan permukiman dan kebakaran hutan. Mengikuti perkembangan tersebut, pemerintah sendiri memberikan upaya perlindungan hukum terhadap hewan langka yang mendapatkan perlakuan tidak wajar oleh oknum-oknum yang tidak bertanggung jawab yang terdiri dari :

a) Perlindungan hukum preventif terdapat dalam peraturan perundang undangan dengan maksud untuk mencegah suatu pelanggaran serta memberikan ramburambu atau batasan-batasan dalam melakukan suatu kewajiban. Salah satu bentuk peraturan yang dibuat oleh pemerintah yakni terdapat pada UndangUndang Nomor 5 Tahun 1990 tentang Konservasi Sumber Daya Alam Hayati dan Ekosistemnya. dan;

b) Perlindungan Hukum Represif yang berupa perlindungan akhir (sanksi) terdapat dalam Undang-undang Nomor 5 Tahun 1990 Tentang Konservasi Sumber Daya Alam Hayati dan Ekosistemnya.

2. Upaya pemerintah Indonesia dalam mengimplementasikan kebijakan yang telah dibuat belum berjalan secara sempurna. Salah satu contoh dengan adanya sistem Online Single Submission (OSS), yang dianggap mengabaikan perlindungan lingkungan hidup sebagaimana dalam kententuan yang ada dalam Undang-Undang No. 32 Tahun 2009 tentang Perlindungan dan Pengelolaan Lingkungan Hidup. Maka dari itu, perlindungan satwa di Indonesia belum sesuai dengan kebijakan yang telah dibuat oleh pemerintah. Sehingga kepastian dalam hukum belum terbentuk secara sempurna sebagaimana yang diketahui bahwa hukum mengandung kepastian manakala hukum itu dapat menyebabkan perilaku manusia, baik individu, kelompok, maupun organisasi terikat dan berada dalam koridor yang sudah digariskan oleh aturan hukum itu sendiri. Nilai kepastian inilah yang harus ada dalam setiap hukum yang dibuat sehingga dapat memberikan rasa keadilan dan menciptakan ketertiban. 


\section{DAFTAR PUSTAKA}

\section{Buku dan Jurnal :}

Amiruddin, Zainal Asikin. Pengantar Metode Penelitian Hukum. Raja Grafindo Persada. Jakarta: Raja Grafindo Persada, 2004.

Aninta, Sabhrina. "Mengapa Satwa Langka Rentan Punah? Genetika Jelaskan." www.sains.kompas.com, 2019.

Dian, Asti. "Perdagangan Satwa Ilegal Ada Di Sekitar Kita Begini Kondisinya." www.mongabay.co.id, 2018.

Fuqoha, Fuqoha, Indrianti Azhar Firdausi, and Arga Eka Sanjaya. "Perlindungan Hukum Terhadap Intervensi Pemberitaan Dalam Kerangka Kemerdekaan Pers Nasional." Ajudikasi: Jurnal Ilmu Hukum Vol. 3, No. 1 (2019): 75. https://doi.org/10.30656/ajudikasi.v3i1.1436.

Hanif, Fathi. "Upaya Perlindungan Satwa Liar Indonesia Melalui Instrumen Hukum Dan Perundang-Undangan." Jurnal Hukum Lingkungan Indonesia 2, no. 2 (2021): 30. https://doi.org/10.38011/jhli.v2i2.24.

Heriani, Fitria Novia. "Sejumlah Hambatan Yang Perlu Disempurnakan Dalam OSS." www.hukumonline.com, 2019.

Mahmud Marzuki, Peter. Penelitian Hukum. Cetakan ke. Jakarta: Kencana, 2008.

ProFauna. "No Fakta Tentang Satwa Liar Indonesia." www.profauna.net, 2003.

Raharjo, Satjipto. Ilmu Hukum. Bandung: PT. Citra Aditya Bakti, 2000.

Remaja, Nyoman Gede. "Makna Hukum Dan Kepastian Hukum." Kertha Widya: Jurnal Hukum 2, no. 1 (2014): 1-26.

Rokilah, Rokilah. "The Role of the Regulations in Indonesia State System." Ajudikasi : Jurnal Ilmu Hukum Vol. 4, No. 1 (2020): 29-38. https://doi.org/10.30656/ajudikasi.v4i1.2216.

Safrizal. "Perlindungan Hukum Terhadap Satwa Liar (Studi Konflik Gajah Dengan Manusia Di Aceh Timur) Menurut Hukum Pidana Islam." Universitas Islam Negeri Ar-Raniry, 2019.

Soekanto, Soerjono. Sosiologi Suatu Pengantar. Jakarta: Raja Grafindo Persada, 2007.

\section{Peraturan Perundang-undangan}

Undang-Undang Dasar 1945

Undang-Undang No.5 Tahun 1990 Tentang Konservasi Sumberdaya Alam Hayati dan Ekosistemnya. 
AJUDIKASI : Jurnal Ilmu Hukum, Volume 5 Nomor 1, Juni 2021. Hlm 83-98

P-ISSN 2613-9995 \& E-ISSN 2614-0179 